\title{
Adattudományi innováció az egészségügy környezeti kihívásainak kezelésében: a nagy adatállományok hasznosításának jelentősége és lehetôségei a járványkezelésben
}

\author{
Gaál Péter ${ }^{1,2,3^{*}}$, Joó Tamás ${ }^{1,3}$, Palicz Tamás ${ }^{1}$, \\ Pollner Péter ${ }^{1,4}$, Schiszler István ${ }^{1}$, Szócska Miklós ${ }^{1}$ \\ ${ }^{1}$ Semmelweis Egyetem, Egészségügyi Közszolgálat Kar, Egészségügyi Menedzserképző Központ, Budapest, Magyarország \\ ${ }^{2}$ Sapientia Erdélyi Magyar Tudományegyetem, Marosvásárhelyi Kar, Alkalmazott Társadalomtudományi Tanszék, \\ Marosvásárhely/Koronka, Románia \\ ${ }^{3}$ Magyar Egészségügyi Menedzsment Társaság, Budapest, Magyarország \\ ${ }^{4}$ MTA-ELTE Statisztikus és Biológiai Fizika Kutatócsoport, Eötvös Loránd Kutatási Hálózat, Budapest, Magyarország
}

Beérkezett: 2021. 05. 03.; Elfogadva: 2021. 06. 14.

\section{Összefoglalás}

A COVID-19 járvány rámutatott arra, hogy az egészségügy kiemelt nemzetbiztonsági terület. Az egészségbiztonsági kockázati tényezőkkel szemben ellenálló egészségügyi rendszerek adattudományi innováció nélkül nem képzelhetők el. A közlemény két esettanulmányon keresztül mutatja be, hogy a nagy, múködés során generálódó adatbázisok elemzése hogyan segítheti a járványokkal szembeni védekezést. A mobilcella információk elemzése a leghatékonyabb eszköz a tömeges népességmozgások nyomon követésére, így a vesztegzár intézkedések hatásának döntéstámogatási célú vizsgálatára, az oltásellenes közösségimédia-aktivitás hálózatelemzése pedig segíti az immunizációs kampányok tervezését és megvalósítását. Tanulmányunkban amellett érvelünk, hogy az egészségügy információ- és kommunikációtechnológia fejlődésére építő digitalizációja a kulcsa egy környezeti változásokkal megbirkózni képes egészségügy kialakításának.

Kulcsszavak: egészségügyi adattudomány, alkalmazkodóképesség, járványkezelés, oltásellenesség, hálózatkutatás

\section{Innovation in Data Science to Address the Environmental Challenges of Health Systems: the Significance and Opportunities of the Analysis of Big Routine Datasets in Pandemic Management}

Péter Gaál ${ }^{1,2,3}$, Tamás Joó1,3, Tamás Palicz ${ }^{1}$, Péter Pollner ${ }^{1,4}$, István Schiszler ${ }^{1}$, Miklós Szócska $^{1}$

\footnotetext{
${ }^{1}$ Semmelweis University, Faculty of Health and Public Administration, Health Services Management Training Centre, Budapest, Hungary

${ }^{2}$ Sapientia Hungarian University of Transylvania, Faculty of Technical and Human Sciences,

Department of Applied Social Sciences, Tîrgu-Mureş, Romania

${ }^{3}$ Hungarian Health Management Association, Budapest, Hungary
}

${ }^{4}$ MTA-ELTE Statistical and Biological Physics Research Group, Eötvös Loránd Research Network, Budapest, Hungary

\section{Summary}

The COVID-19 pandemic has shown that health and health care should be considered a top priority area of national security. Health security risks can only be addressed with resilient health systems, which are not possible to be established without innovation in health data science. This publication introduces two examples to illustrate this point, 
both in the field of the management of epidemics. The first case provides a summary of our previous publication about how mobile phone Call Detail Records can be used to trace population movement to evaluate the effectiveness of movement restriction measures, such as the lock down, which was implemented in Hungary during the first phase of the COVID-19 pandemic. Our analysis shows that the collation and processing of Call Detail Records is an effective and inexpensive method to monitor mass population movement, and complements well the GPS-based smartphone method, which is more suitable for contact tracing and controlling of home quarantine of individuals. Our CDR-based method could be used by other countries, as well as to monitor movement between countries at the European level or internationally, with minimal adaptation effort. The second case introduces a study to gain insight into and better understanding of the potential impact of antivaccination social media activism on the Human Papilloma Virus vaccination campaign in Hungary in 2014. The network analysis of Facebook antivaccination posts and comments showed that during this period, the activists in this network were unable to reach a wider population and were not able to disturb the implementation of the expansion of the well functioning Hungarian public vaccination programme. Unfortunately, this is not the case regarding the COVID-19 vaccination campaign in progress, which suggests that the antivaccination activism is a real and serious security threat to be dealt with. In conclusion, we argue in this paper that the digital transformation of health care, based on the explosive development of information and communication technologies, is of key importance to the establishment of resilient health systems, which are able to cope efficiently with the challenges posed by the rapid environmental changes generated by societal transformation of the $21^{\text {st }}$ century.

Keywords: health data science, resilience, pandemic management, antivaccination activism, network analysis

\section{Bevezetés}

A COVID-19-járvány minden korábbinál erősebb és kézzelfoghatóbb példát szolgáltatott arra, hogy az egészség, illetve az egészségügy kiemelkedő jelentőségú biztonsági tényező bármely ország múködőképessége, stabilitása és fenntartható fejlődése szempontjából (World Health Organization 2020, 2021a). A világ országainak kormányait annak ellenére érte felkészületlenül a 2019 végén ránk törő járvány, hogy a fertőző betegségek jelentette fenyegetésre a szakértők már több évtizede figyelmeztettek és több kisebb kiterjedésú járvány, többek között a Súlyos Heveny Légzószervi Tünetegyüttes (SARS, SARS-CoV) 2002-2003-ban, illetve a Közel-keleti Légzőszervi Tünetegyüttes (MERS, MERS-CoV) 2012-2014-ben fel is ütötte a fejét (World Health Organization 2021b, 2021d). Igaz azonban, hogy ezek végül is nem tudtak világjárvánnyá fejlődni, és a fertőző betegségek társadalmi alrendszerek múködésére gyakorolt szétziláló hatása csak a COVID-19 világjárvánnyal vált lényegében minden országban a hétköznapok megkerülhetetlen valóságává. Ennek kapcsán lett kulcskérdés az, hogy hogyan lehet az ilyen és ehhez hasonló egészségbiztonsági kihívásokat hatékonyan kezelni.

Az egészségügyi rendszerekkel kapcsolatos kormányzati gondolkodást a 2000-es évek végéig elsősorban a gyors technológiai fejlődés generálta költségrobbanás hatékonyságjavító intézkedésekkel történő megfékezése határozta meg, amikor a kirobbant pénzügyi, gazdasági világválsággal összefüggésben először fogalmazódott meg az a kérdés, hogy hogyan lehet a hirtelen bekövetkező, sokkszerú környezeti változásokkal szemben ellenálló, alkalmazkodóképes egészségügyi rendszereket építeni (Gaal 2004; Gaal 2005; Gaal-Stefka-Nagy 2006; Gaal et al. 2011; Jacobs-Smith-Street 2006; Szigeti et al. 2019). Ezen ellenálló, illetve alkalmazkodóképesség (resilience) felértékelődése, középpontba helyeződése annak a felismerésnek tulajdonítható, hogy a XXI. században felgyorsult az egészségügyi rendszerek (és más társadalmi alrendszerek) múködését meghatározó környezet változása, és ez folyamatosan újabb és újabb, sokszor egymásnak ellentmondó kihívásokat támaszt, amelyeknek egyre nehezebben tudnak megfelelni (Gaál 2019; Girasek et al. 2017; Thomas et al. 2020). Amíg például a rapid orvostechnológiai innováció a specializáció és ezen keresztül a fragmentáció irányába hat, addig az elöregedéssel együtt járó krónikus nem fertőző betegségek halmozódása a különböző ellátási szintek és egészségügyi szolgáltatók koordinált, integrált múköódését kívánná meg (Gaál 2019; Gaal et al. 2011). Szerencsére az egészségügy környezetének változása nemcsak a fenntartható, jó teljesítményt veszélyeztető fenyegetéseket, hanem a teljesítmény javítását elősegítő lehetőségeket is generál. Ilyen nagy horderejű lehetőség az információés kommunikációtechnológiai (ICT) környezet egyre gyorsuló fejlődése, amely minden bizonnyal az egyik kulcsa lehet az ellenálló és alkalmazkodóképes egészségügyi rendszerek kialakításának.

A külső hatások kivédése, illetve az azokhoz való alkalmazkodás ugyanis elképzelhetetlen adatok, információk nélkül. Az eredményes megküzdési stratégiák kialakításához először észlelni szükséges a környezeti feltételek megváltozását, elemezni kell azt, ennek alapján meg kell találni a megfelelő válaszreakciót, majd pedig figyelemmel kell kísérni, értékelni kell annak környezetre gyakorolt hatását (Thomas et al. 2020). A modern ICT eszközök rendelkezésre állása lehetôvé teszi nagy mennyiségú adat célzott gyújitését, tárolását és feldolgozását, így lényegében a problémák időben történő felismerését és a gyors, adekvát válaszreakciót. A modern társadalmak múködése során ugyanakkor - éppen az ICT-forradalomnak köszönhetóen - rengeteg adat keletkezik és rög- 
zül rutinszerúen is, amelynek feldolgozásában, értelmezésében a lehetőségek széles tárháza rejlik. Az adattudományi innováció célja pedig az, hogy feltárja ezeket a lehetőségeket az adatok összekapcsolásával és újszerú módszerek alkalmazásával.

Ebben a cikkben arra mutatunk két példát, hogy a nagy, múködés során automatikusan generálódó adatállományok elemzésével hogyan segíthető a járványok leküzdése, így közvetetten amellett érvelünk, hogy az adattudománynak meghatározó szerepet kell betöltenie az egészségügyi biztonsági kockázatok kezelésében, az ellenálló és alkalmazkodóképes egészségügyi rendszerek kialakításában.

\section{Vizsgálati anyag és módszer}

Az egészségügyi adattudomány módszereinek járványkezelésben történő alkalmazásának lehetőségeit egy korábbi közleményünkben már áttekintettük (GaálSzócska 2020). Ebben a cikkben elsősorban a konkrét, gyakorlati megvalósítás eredményeire fókuszálunk két kutatási projekt áttekintő bemutatásával.

Bármilyen járvány leküzdésére, így a COVID-19 világjárvány esetében is, mindössze néhány megoldási lehetőség jön szóba (Denworth 2020). Vagy sikerül elérni, hogy a lakosság döntő többsége védettséget szerezzen a fertőzéssel szemben (nyájimmunitás), vagy pedig rendelkezésre áll olyan kezelés, amely a megbetegedetteket meggyógyítja, vagy legalábbis megakadályozza, hogy jelentős egészségügyi kapacitásokat lekötő, súlyos, akár halállal végződő betegség alakuljon ki. A nyájimmunitás pedig vagy oltással, vagy pedig a lakosság átfertőződésével érhetố el. A természetes úton létrejövő nyájimmunitás a COVID-19 járvány esetében nem jelentett megvalósítható intézkedési lehetőséget, annak ellenére, hogy kezdetben úgy túnt, több ország is megpróbálkozik vele (Conn et al. 2020; Weintraub 2020). Ez ugyanis abban az esetben is katasztrófához vezetett volna, ha a statisztikai adatok szerint fokozottan veszélyeztetett csoportokat, azaz az időseket és/vagy krónikus betegeket szigorú elkülönítéssel igyekeztek volna megvédeni, hiszen a súlyos/halálos kimenetel a fiatal egészséges felnőttek között sem volt kizárható, a járvány szabadjára engedése pedig ebben a csoportban is tömeges megbetegedéseket, illetve halált okozott volna, annak minden drámai, társadalmi, gazdasági következményével együtt. Mindaddig tehát, amíg hatásos oltás (vagy kezelés) nem volt elérhetó, a terjedés akadályozása volt az egyetlen eszköz a döntéshozók kezében a járvány kordában tartására.

A COVID-19 járványt okozó SARS-CoV-2 olyan vírus, amely elsősorban a vírusrészecskéket megfelelő koncentrációban tartalmazó levegő belélegzésével, valamint az orr, a száj, illetve a szemek vírusrészecskékkel szenynyezett kézzel történő érintése útján terjed, tehát terjedéséhez arra van szükség, hogy a fertőzött és a nem fertőzött emberek egymással közeli kapcsolatba kerüljenek (Helfgott 2020). Fizikai távolságtartási intézkedésekkel (social distancing) jelentôs mértékben csökkenthető a fertőzés terjesztésére alkalmas kapcsolatok száma, amennyiben pedig az érintkezések elkerülhetetlenek, a különböző védőfelszerelések használata (personal protective equipment, $P P E$ ) jelenthet megoldást a fertőzés terjesztésének és a megfertőződés kockázatának csökkentésére (Centers for Disease Control and Prevention 2021; Maragakis 2020; World Health Organization 2021c). A fizikai távolságtartási intézkedések, mint például a vesztegzár sikeres alkalmazása nagymértékben attól függ, hogy az emberek mennyire hajlandók önkéntesen is együttmúködni ezeknek az intézkedéseknek megvalósításában, mivel a szabályok betartásának kikényszerítéséhez szükséges kapacitások korlátozott mértékben állnak rendelkezésre, és tömeges engedetlenség esetén a többség büntetlenül megúszhatja a szabályok megsértését (Regulatory Management and Reform Group of the Public Management Committee 2000; Scholz 1984). Éppen ezért a járványkezelésben kiemelt jelentősége van annak, hogy a lakosság mozgását megfelelő részletességgel nyomon lehessen követni, amely segít időben felismerni a problémás pontokat, és lehetôvé teszi a célzott beavatkozásokat a járvány megfékezéséhez rendelkezésre álló erőforrások optimális felhasználása érdekében.

Az első esettanulmány egy olyan kutatási projektet mutat be, amelyben az innovatív adattudományi megközelítést a fizikai távolságtartási intézkedések hatásának nyomon követésére alkalmas döntéstámogató rendszer kiépítéséhez használtuk fel. Az a gondolat, hogy a mobiltelefonok használata során generált adatok felhasználhatók a lakosság mozgásának nyomon követésére, egyáltalán nem új, jól ismert a szakirodalomból, ugyanakkor alig találni olyan tanulmányt, amely részletes módszertani útmutatást adna ahhoz, hogy a mobilcella információkat tartalmazó, mobiltelefon szolgáltatói adatbázisok hogyan kapcsolhatók össze egy olyan egységes, országos lefedettséget, de egyben részletes felbontást is biztosító döntéstámogató rendszerré, amely nem igényli az egyes egyének önkéntes jóváhagyását, és mégis megfelel a személyes adatok védelmével kapcsolatos szigorú jogszabályi követelményeknek (Balzotti et al. 2018; BlondelDecuyper-Krings 2015; Eagle 2011; Grantz et al. 2020; Oliver et al. 2020). Az itt ismertetett első kutatási projekt az Innovációs és Technológiai Minisztérium által a Semmelweis Egyetem Egészségügyi Közszolgálati Karán létrehozott Digitális Egészségügyi és Adathasznosítási Munkacsoport tagjainak munkája, amely éppen annak érdekében jött létre, hogy feltérképezze a COVID-19 járvány kezelésében használható nagy adatbázisokat és kidolgozza az ezekből kinyerhető döntéstámogató információk becsatolását a járványkezeléssel kapcsolatos stratégiai és operatív döntéshozatalba. A magyarországi három legnagyobb, a piac közel 100\%-át lefedő mobilszolgáltató közremúködésével létrehozott döntéstámogató rendszer jelenleg is múködik, és folyamatosan információt szolgáltat a járványügyi intézkedések meghozatalához. 
A járvány leküzdésében végső megoldást természetesen a védőoltásokkal elérhető nyájimmunitás jelenti, amelynek azonban csak egy, vitathatatlanul fontos eleme a hatásos vakcina rendelkezésre állása. Ugyanennyire fontos a lakossági oltási hajlandósága, amelyre komoly hatást gyakorolnak a Magyarországon is egyre nagyobb teret nyerő oltásellenes mozgalmak (Portfolio 2021). Paradox módon az oltásellenes nézetek terjesztésének éppen az ICT fejlődése adott lökést az egész világot behálózó közösségimédia-platformok létrejöttén és népszerűvé válásán keresztül, amely hatékonyan és lényegében kontroll nélkül juttatja el a felhasználókhoz az információt, függetlenül annak hitelességétől, tudományos megalapozottságától (Doktor Gödény 2021). A nyilvános közösségi médiumokon keresztül történő információmegosztás adattudományi módszerekkel történó elemzése ugyanakkor segíthet a mozgalmak múködésének és információterjesztési stratégiáinak megértésében és ezáltal értékes adatokat szolgáltathat célzott beavatkozások tervezéséhez.

A második esettanulmány erre mutat példát, amelynek célja a Human Papilloma Vírussal (HPV) szembeni vakcinációs kampány sikerének biztosítása volt az oltásellenes közösségimédia-aktivitás feltérképezésével, elemzésével. Ez a projekt időben megelőzte a COVID-19 járvány kitörését, de tapasztalatai, illetve a felhasznált módszerek jól alkalmazhatók a koronavírussal kapcsolatos oltási kampány tervezésében és megvalósításában, hiszen az oltásellenes aktivitás itt újra felerősödött és jelentős teret nyert annak ellenére, hogy a súlyos megbetegedések, illetve a járványnak tulajdonítható többlethalálozások ebben az esetben azonnali és kézzelfogható bizonyítékot szolgáltatnak arra, hogy milyen nagy szükség lenne a járvány terjedését megállító mértékű átoltottság minél hamarabb történő elérésére.

A két kutatási projektet esettanulmányszerüen foglaljuk össze. A mobiltelefon cellainformációk feldolgozására épülő, a karanténintézkedések a lakosság mozgására gyakorolt hatását monitorozó módszertan ismertetése egy angol nyelven megjelent összefoglaló fordításán alapul, amelynek magyar nyelven történő közlésére az eredeti forrás megjelölése mellett engedélyt kaptunk (Gaal et al. 2021). A módszertant és az eredményeket egy másik angol nyelven megjelent publikációban részleteztük (Szocska et al. 2021), az oltásokkal foglalkozó kutatás eredményeiról azonban ebben a cikkben számolunk be először. Tekintettel arra, hogy a cikk két egymástól eltérő módszertannal megvalósított és nagyon különböző eredményekkel rendelkező projektet foglal össze, a specifikus módszertant, az eredményeket és azok megbeszélését nem fejezetekre bontva, hanem projektenként együttesen mutatjuk be. A végső következtetéseket ugyanakkor a két projektre közösen, a téma átfogó kontextusában vonjuk le.

\section{Vizsgálati eredmények}

\section{A lakosság mozgásának járványügyi célú nyomon követése mobiltelefon cellainformációk feldolgozásával}

Ahogy arra korábban már utaltunk, a rutinszerüen keletkező, múködési típusú nagy adatbázisok összekapcsolására és innovatív módszerekkel történő másodelemzésére egyre inkább tekintenek úgy, mint a tudományos bizonyítékokon alapuló programalkotás leghatékonyabb eszközére (Munné 2016). A mobiltelefon generálta adatok mozgás-monitorozási célú felhasználása régóta ismert és alkalmazott technika, amelynek bevetése a járványok megfékezésére természetesen a COVID-19 járvány kapcsán is elötérbe került (Grantz et al. 2020; Oliver et al. 2020). A mozgáskorlátozó intézkedések hatásának nyomon követésére kézenfekvő választás a cellaadatok (Call Detail Records, CDR) feldolgozása, hiszen a mobilhálózat adótornyai automatikusan rögzítik az adótorony földrajzi helyzetét minden egyes telefonhasználat során, amely jó közelítéssel alkalmas a mobiltelefon, és ezáltal az eszközt használó személy hozzávetőleges lokalizációjára, és ehhez, szemben az okostelefonok által használt GPS-alapú helymeghatározással, nincs szükség az előfizető külön jóváhagyásra sem. Az ötlet megvalósítása során azonban számos technikai jellegû részletkérdés merül fel. Nem magától értődő például az, hogy hogyan rendezhetők egy adatbázisba a különböző telekommunikációs cégek által, különböző formátumban generált adatok, vagy az, hogy hogyan biztosítható a személyes adatok védelmét szolgáló jogszabályi előírások, mint az Európai Unió általános adatvédelmi szabályozása (General Data Protection Regulation, GDPR) teljes körú érvényesülése.

A Digitális Egészségügyi és Adathasznosítási Munkacsoport a három nagy magyar mobilszolgáltatóval együttmúködésben olyan módszertant dolgozott ki, illetve olyan döntéstámogató rendszert épített fel, amely megoldotta mindezen technikai megvalósíthatósági problémákat (Szocska et al. 2021). A módszertan legfontosabb elemei a következők voltak. Először is az anonim CDR adatokat települési szinten egy 24 órás ( 1 napos) időszakra vonatkozóan aggregáltuk, és az egyes telekommunikációs vállalatok már csak ezeket az aggregált adatokat bocsájtották rendelkezésre az elemzés céljára. Ez kétséget kizáróan biztosította, hogy egyes konkrét személyek nem voltak azonosíthatóak, így a módszertan megfelel még a legszigorúbb adatvédelmi előírásoknak is, ugyanakkor ez a választás nem rontotta a módszer használhatóságát sem, hiszen a populációs szintű mozgások nyomon követésében nincs szükség egyes emberek teljesen pontos földrajzi helyének meghatározására. Ez utóbbit a CDR adatok egyébként sem teszik lehető- 
vé, mert a mobiltelefon-használat során nem a készülék, hanem a kommunikációt végzô adótorony helyzetét rögzítik. Az így aggregált adatokból úgy készítettünk összesítést, hogy az adott 24 órás időszakban egy lokalizációt mutató telefonokat helyben maradóként, a több lokalizációban megjelenőket pedig mozgóként azonosítottuk, amelyből azután úgynevezett „helybenmaradási”, illetve „mozgási” indexet számoltunk. Másodszor, az így kapott adatokat nem abszolút számként, hanem egy releváns, a járvány kitörése előtti időszak adott napjainak átlagértékéhez mint referencia időszakhoz viszonyított relatív értékként jelenítettük meg az indexekben annak érdekében, hogy a mozgásaktivitásban jelentkező periodikus változások okozta volatilitás zavaró hatását kiküszöböljük. Harmadszor, kidolgoztuk a különböző mobilszolgáltatóktól érkező adatok összefésülésének módszertanát. Ennek egyik fontos eleme volt például az, hogy minden szolgáltató minden adótornyát egységes elvek mentén, egyértelmúen egy-egy településhez rendeltük, így nem okozott gondot a különböző szolgáltatókhoz tartozó kártyák CDR adatainak települési szintú aggregációja.
Az 1. ábrán bemutatjuk az így képzett „otthonmaradási” és „mozgási” indexek értékének változását a járvány magyarországi kitörését közvetlenül megelőző időszaktól kezdve az első hullám legintenzívebb időszakával bezárólag. Az ábrán jól látható a 2020. március közepén bevezetett korlátozó intézkedések hatása, valamint az újabb szigorítások meghirdetése után, azok bevezetését megelőző időleges kiugrások, amelyek a raktározási célú vásárlási láznak tulajdoníthatók.

Tekintettel arra, hogy a módszertan települési szintű felbontást is lehetővé tesz, nagyon jól nyomon követhetők vele a helyi szintü kiugrások, amelyek alapját adhatják célzott, lokalizált intézkedések bevezetésének. Ez javítja a korlátozó intézkedések hatékonyságát, mivel csak ott avatkozik be, ahol az szükséges, és így nem hárít felesleges többletterhet a felelősen viselkedő lakosokra. A 2. ábrán erre mutatunk példát, szintén a járvány első hullámából. A Balaton környéki településeken megsokszorozódó mozgási aktivitás megerósítette azokat a pletykaszerúen terjedő információkat, hogy a városi, elsősorban fóvárosi lakosok a nyaralóikban kívánták átvészelni a legnehezebb időszakot, akaratlanul is lökést adva

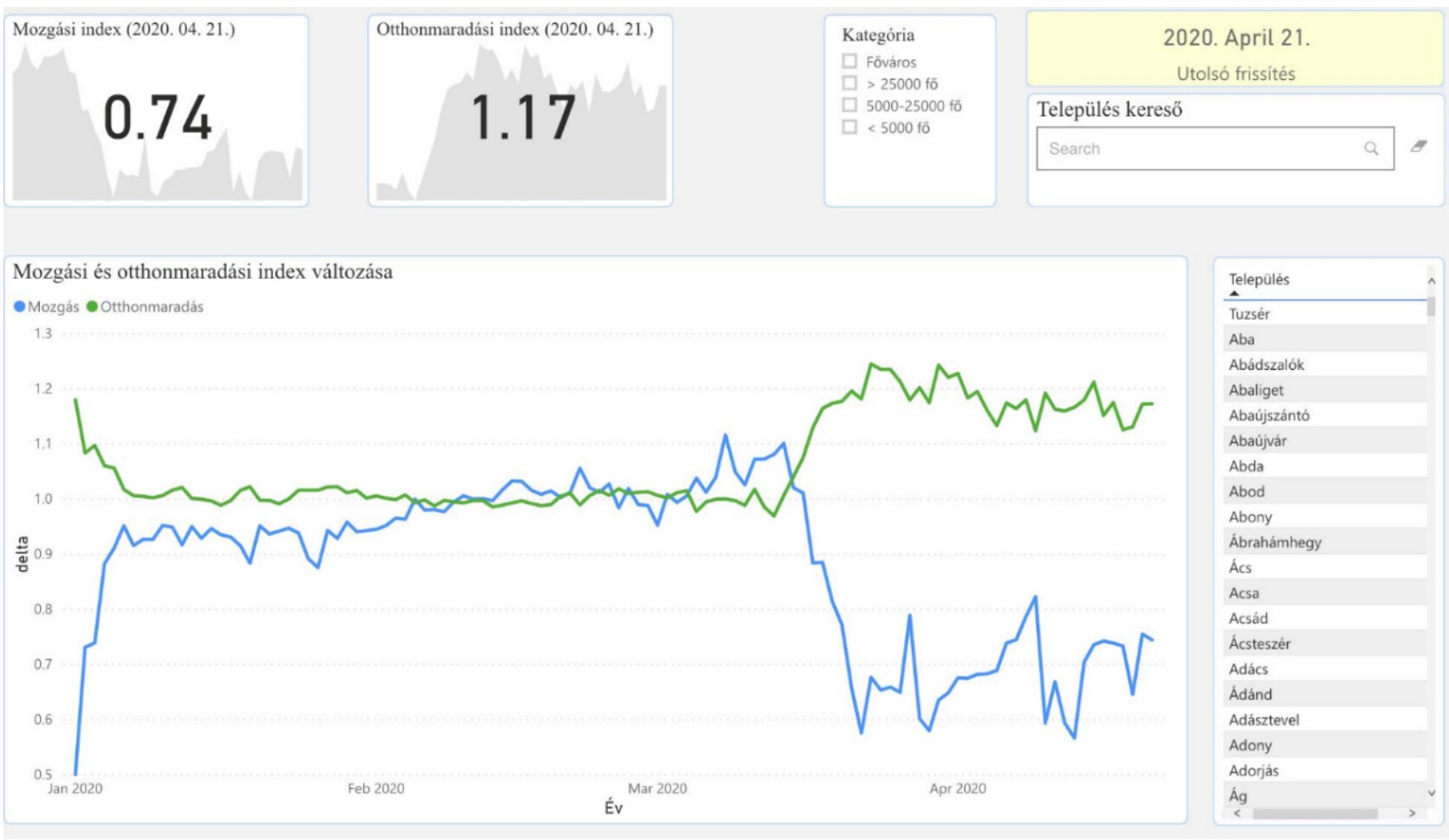

Mozgás index Honnan-hová indexek Megyei indexek Megyén belüli mozgások Módszertan

1. ábra $\quad$ Példa a „mozgási” (kék), illetve az „otthonmaradási” (zöld) indexek változásának grafikus ábrázolására a COVID-19 járvány magyarországi első hullámának időszakából, 2020. január - 2020. április

Forrás: Saját szerkesztés (Gaal et al. 2021: átvéve az ERCIM engedélyével) 


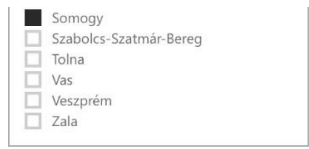

Arány Megyénké $\nabla$

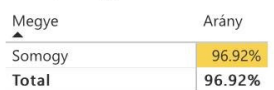

Totat

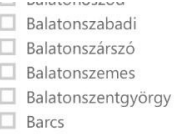

Barcs

Arány Településenként

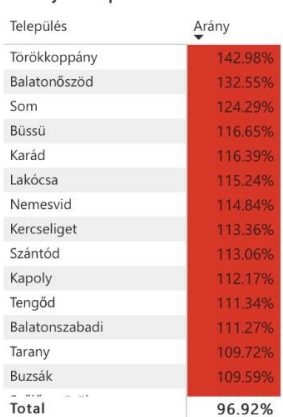

Piros: Arány $>=100 \%$ Sárga: $75 \%=<$ Arány $<100 \%$ Kék: Arány $<$

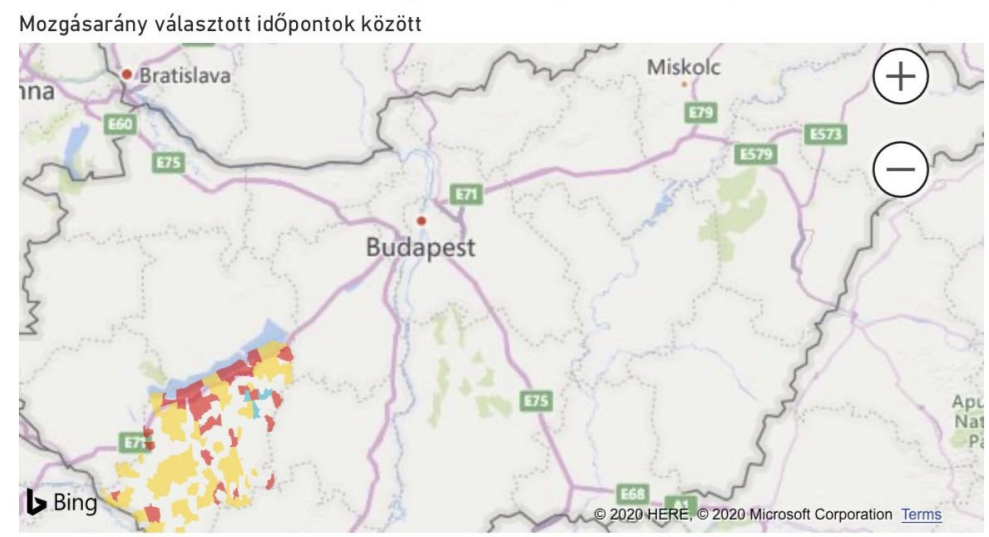

2. ábra

Példa a „mozgási” index települési szintű különbségeire a COVID-19 járvány magyarországi első hullámának időszakából (piros színnel színezett település $\geq 100 \%$, sárga 75\%-99,99\%, kék <75\%)

Forrás: Saját szerkesztés

ezzel a járvány terjedésének. A kormány erre reagálva rendeletben tette lehetővé a települések helyi vezetésének azt, hogy az országos intézkedéseknél szigorúbb korlátozásokat vezessenek be saját településeik közigazgatási határain belül (Kormány 2020). A települési szintü adatok elemzése során ugyanakkor felmerülhet kérdésként, hogy mennyiben teljesülnek a személyes adatok védelmével kapcsolatos, korábban említett megfontolások azokban az esetekben, ahol a településen lakó népesség száma nagyon alacsony. Magyarországon a 2020. január 1-én a legkisebb község a Zala megyei Iborfia volt, 11 lakossal (Belügyminisztérium Nyilvántartások Vezetéséért Felelös Helyettes Államtitkárság 2021). Meggyőződésünk, hogy a kidolgozott módszertan alapján ez sem jelent problémát, tekintettel arra, hogy a mobilszolgáltatók nem adnak ki személyazonosításra alkalmas adatokat, és az egyes rekordok a települési szinten, 24 órás periódusonként aggregált mozgó, illetve helyben maradó mobiltelefonok összesített számát tartalmazzák, amelyből nem állapítható meg, hogy az adott mobiltelefonok helyi lakosokhoz tartoznak-e, vagy sem, mert a helyi lakosok is mozoghatnak, valamint a nem helyi lakosok is lehetnek helyben maradók. Így tulajdonképpen mindig érvényesül a k-anonimitás (Sweeney 2002). Ha előállna az az extrém eset, hogy egy településen egyetlen mobiltelefon detektálható egy adott napon, az elemzésre átadott adatokból akkor sem lenne azonosítható a tulajdonos személye, hiszen még az sem állapítható meg, hogy állandó lakos telefonjáról van-e szó, vagy sem.

Összefoglalóan elmondható, hogy a Munkacsoport által kifejlesztett módszertannal sikerült olyan egyszerú döntéstámogató alkalmazást kifejleszteni, amely a CDR adatok felhasználásával kapcsolatos összes technikai megvalósíthatósági kérdésre választ ad. A bemutatott eredmények demonstrálják azt, hogy a CDR-alapú módszertan jó és olcsó eszköze a járványügyi érdekből vég- zett populációs mozgásmonitorozásnak, amely kellően pontos és megfelelő felbontást tud biztosítani a szükséges távolságtartó intézkedések tervezéséhez, megvalósításához és értékeléséhez. Bár a mobiltelefon cellainformációinak elemzésére épülő mozgás nyomon követése nem új ötlet, és a jelenlegi COVID-19 járványban is több országban használták már rajtunk kívül is, legjobb tudásunk szerint egyetlen közlemény sem foglalkozott még a módszertan technikai részleteinek bemutatásával.

A CDR adatok elemzése ugyanakkor nem az egyetlen lehetőség az emberek mozgásának vizsgálatára. Az egyre szélesebb körben használt okostelefonok a cellainformációk mellett GPS-szel is rendelkeznek, amely jóval pontosabb helymeghatározást tesz lehetővé (Google Inc 2020). Hátránya azonban az, hogy ehhez az előfizetőnek nemcsak magával az okos készülékkel kell rendelkeznie, hanem be is kell kapcsolni a GPS érzékelőt, valamint engedélyt kell adnia a helyadatokhoz való hozzáféréshez, a helyadatok használatához. A megjelent közleményünkben részletesen összehasonlítottuk a két módszertant, és arra a következtetésre jutottunk, hogy a CDR-alapú helymeghatározás számos tekintetben jobb a tömeges, populációs szintú mozgások nyomon követésére, mint a GPS-alapú, míg az utóbbi alkalmasabb az egyes személyek helyváltoztatásának detektálására, amelynek inkább a kontakt személyek felkutatásában, vagy a személyes, otthoni vesztegzár betartásának ellenőrzésében lehet szerepe. Ennek megfelelően a két módszer egymásnak sokkal inkább kiegészítője, mintsem versenytársa.

Tekintettel arra, hogy az általunk kifejlesztett módszertan három, nagy nemzetközi telekommunikációs vállalat adatainak integrációjára épül, hogy a kidolgozott algoritmusok automatikusan alakítják át ezeket a hatalmas adatbázisokat a döntéshozók számára könnyen értelmezhető információvá, valamint arra, hogy a folyamat standardizált és elég gyors ahhoz, hogy releváns legyen a 
mindennapi döntéshozatalban, meggyőződésünk, hogy megfelelő adaptációval könnyen használható lenne más országokban is, vagy akár az országok közötti mozgások nyomon követésére európai, illetve nemzetközi szinten.

\section{Az oltásellenes közösségimédia-aktivitás vizsgálata hálózatelemzési módszerekkel}

Ennek a kutatási projektnek a keretében 2014 őszén vizsgáltuk a HPV oltási kampánnyal kapcsolatos kockázatokat, amelyek között egyre nagyobb jelentőséggel bír az oltásellenesség terjedése. Annak ellenére, hogy a magyar kötelező oltási program az egyik legjobban múködő a világon, 98\% feletti átoltottsági aránnyal minden kötelező oltás esetében (World Health Organization 2017), a különböző oltásellenes társadalmi csoportoknak rendszeresen sikerül elérnie, hogy a sajtó figyelmet szenteljen nekik, ez pedig alááshatja a kötelező oltásokba vetett közbizalmat, amely végső soron az átoltottsági mutatók csökkenéséhez vezethet. Különösen nagy lehet ez a koc- kázat, amikor egy új oltás bevezetése a cél. Bár a HPVoltás serdülő lányok körében történő bevezetésével kapcsolatos döntés körül nem voltak politikai csatározások és a jogszabály a 2014/15-ös iskolai évtól tette ajánlottá az oltás felvételét (Dósa-Hanti-Kovácsy 2017), nem lehetett biztosan tudni, hogy a felélénkülő oltásellenesség nem gyengíti-e meg jelentős mértékben az oltási hajlandóságot.

A kutatás célja annak vizsgálata volt, hogy az oltásellenes csoportok közösségi médiában kifejtett tevékenysége mennyire fenyegeti a magyar oltási portfólió bővítésére irányuló erőfeszítések sikerét. Ennek megállapítására a Facebookon zajló, nyilvános antivakcinációs aktivizmus kiterjedtségét és potenciális hatását vettük górcső alá. A Facebookra azért esett a választás, mert az elmúlt években ez vált a közösségi médián keresztül zajló társadalmi és politikai aktivitás legfontosabb platformjává, és bár a Facebook használata a teljes magyar lakosság körében nem kiemelkedően magas, a HPV-oltás célcsoportja az az X, illetve Y generáció, amely az átlagnál jóval

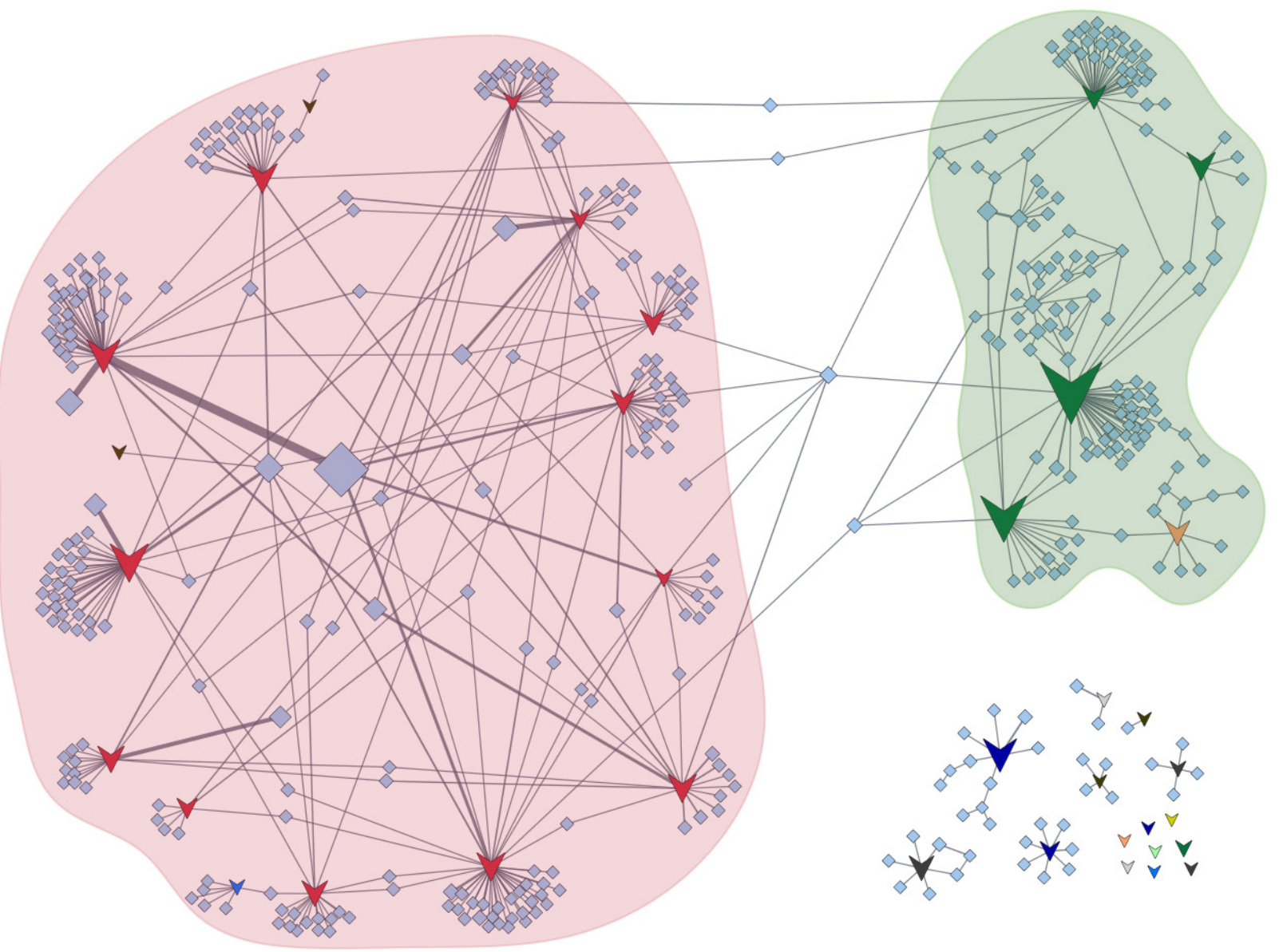

3. ábra

A HPV-oltással kapcsolatos oltásellenes mozgalom mögött húzódó Facebook-hálózat vizualizációja Magyarországon, 2014-ben. (Az ék alakú csomó pontok olyan posztokat reprezentálnak, amelyek egy HPV-oltással kapcsolatos, előre meghatározott kulcsszólista legalább egy elemét tartalmazták. A rombusz alakú csomópontok azokat a felhasználókat jelentik, akik kommentálták ezeket a posztokat. A rombusz alakú csomópontok közötti összeköttetések a kommentekre adott kommenteket reprezentálják. A csomópontok mérete arányos a megosztások, illetve lájkok számával, az összekötő vonalak vastagsága pedig a kommentek számával. A színes háttér a két nagyobb hálózati alakzatot határolja le, amelyet négy felhasználó köt össze.)

Forrás: Saját szerkesztés 
aktívabb ebben a tekintetben, és életének jelentős része eleve az interneten keresztül zajlik.

Az elemzéshez szükséges adatok megszerzését az tette lehetővé, hogy a Facebook esetében lehetôség van célzott kommunikációs adatok letöltésére (posztok, kommentek, felhasználónevek). A kutatás időpontjában a Facebook széles körú és rugalmas hozzáférést biztosított az egyébként is nyilvános adatokhoz, amelyeket az elérhető Application Programming Interface-en keresztül (API) automatizált módon tudtuk összegyújiteni. A szabályozási környezet az adathozzáférés tekintetében azóta jelentősen szigorodott, így az akkor alkalmazott módszertan alapján a vizsgálat a jelenlegi körülmények között nem lenne reprodukálható, de megfelelő indokkal, hatósági eljárás alapján a szükséges adatokhoz a Facebook jelenleg is hozzáférést biztosít.

Az oltásellenes közösség szerkezetét, véleményvezéreinek azonosítását a felhasználói aktivitást és kapcsolatokat reprezentáló hálózatelemzési vizualizáción keresztül tártuk fel, illetve végeztük el. A hálózatot azon posztok alapján rajzoltuk meg, amelyek legalább egyet említettek az előre meghatározott HPV-hez kapcsolódó kulcsszavak közül. Ehhez hozzákapcsoltuk azokat a felhasználókat is, akik érdeklődést mutattak a téma iránt. Az érdeklődést az alapján határoztuk meg, hogy bizonyos posztoknak szerzői voltak, vagy megjegyzést füztek ilyen posztokhoz. A lájkok és a megosztások számát arra használtuk, hogy a különböző posztokat, illetve kommenteket jelentőség szerint megkülönböztessük egymástól.

A 3. ábra az ezen elvek mentén összeállított hálózatot mutatja be. A színes ék alakú szimbólumok az egyes posztokat reprezentálják (a különböző színek különböző Facebook-oldalakat jeleznek), míg a rombusz alakzat kommentelő felhasználókat ábrázol. Az alakzatok mérete arányos azzal, hogy az adott posztot vagy felhasználót hányan osztották meg, illetve lájkolták, a kapcsolatokat reprezentáló összekötő vonalak vastagsága pedig a kommentek számával arányosan nő. Az ábrán az is észrevehető, hogy bizonyos kommentekhez mások további kommenteket is füztek, és ezek a kapcsolatok két jelentősebb közösséget határolnak le, amelyek közepén egy-egy csomópont (véleményvezér, illetve poszt) áll. Ezt a két, relatíve nagyobb közösséget összesen négy felhasználó köti össze. Az ezeken a hálózatokon kívül eső felhasználók ugyanakkor nem voltak képesek érdemi diszkussziót generálni, és az általuk indított posztok csak minimális figyelmet kaptak. Ez utóbbiak a 3. ábra jobb alsó szélén láthatók, kis méretú hálózati alakzatokként.

A hálózatelemzés eredményei azt mutatják, hogy az oltásellenes közösségimédia-aktivitás lényegében néhány Facebook-oldalra korlátozódott, amelyek csak laza öszszeköttetésben álltak egymással néhány kommentelő felhasználón keresztül. A hálózatok mérete arra enged következtetni, hogy a téma nem volt képes jelentősebb közönséget vonzani, az oltásellenes nézetek nem terjedtek tovább. Összességében elmondható tehát, hogy az oltásellenes mozgalom Facebookon kifejtett tevékenysé- ge olyan korlátozott jelenség volt, amely nem jelentett veszélyt a HPV oltási kampányra, így kezelése nem igényelt semmiféle célzott intézkedést sem. A HPV oltás bevezetése ennek megfelelóen sikerrel zárult. Az első évben az érintett szülők 80\%-a kérte az oltást. Az elemzés alátámasztotta azt, hogy Magyarországon az oltásellenes csoportok akkor még nem tudtak érdemi teret nyerni ahhoz, hogy az oltási programok sikerét veszélyeztessék. Sajnos ez a jelenleg zajló COVID-19 járványnyal kapcsolatban már nem mondható el. Az oltási hajlandóság felméréséből származó adatok arra utalnak, hogy a lakosság járványügyi szempontból nem elhanyagolható része nem fogja önként beoltatni magát (Ipsos 2021), amelyben minden bizonnyal jelentős szerepe van a maguknak jelentős médiafigyelmet kiharcoló, oltásellenes véleményvezéreknek, akiknek követőtábora több százezerre tehető. Az oltásellenes csoportok tehát olyan egészség-, illetve nemzetbiztonsági kockázati tényezővé nőtték ki magukat, amellyel érdemben foglalkozni kell, és a közösségimédia-aktivitás elemzése, nyomon követése a megváltozott feltételek ellenére is reális lehetőség ennek a kockázatnak a becslésére, valamint a megfelelő intézkedések kiválasztásának és implementációjának támogatására.

\section{Vizsgálati eredmények értékelése, megvitatása, összefoglalása és következtetések levonása}

Ebben a tanulmányban arra mutattunk példákat, hogy a nagy, múködés során generálódó adatbázisok összekapcsolásával és innovatív eszközökkel történő elemzésével foglalkozó egészségügyi adattudomány hogyan segíthet megbirkózni a nemzetbiztonsági kockázatot is jelentő egészségügyi fenyegetésekkel, mint amit a COVID-19 világjárvány is jelent. A gyorsan változó környezeti feltételek olyan egészségügyi rendszerek kiépítését igényli, amelyek képesek kivédeni ezeket a fenyegetéseket, illetve rugalmasan alkalmazkodni a környezeti változásokhoz. Bár a nemzetközi szakirodalomban nincs egyértelmú, világos ajánlás arra vonatkozóan, hogy hogyan kellene ellenálló-, valamint alkalmazkodóképessé alakítani az egészségügyet, mi amellett érvelünk, hogy ennek meghatározó eleme kell hogy legyen az ICT fejlődése adta lehetőségek maximális kihasználása, az egészségügyi adattudományi innováció.

A tanulmányban bemutatott két példa, a mobiltelefon cellainformációk populációs mozgások nyomon követésére és a hálózatelemzés oltásellenesség kockázatfelmérésére történő felhasználása, korántsem fedi le a lehetőségek teljes körét még a járványkezelés területén sem. Egy másik közleményünkben számos egyéb beavatkozási pontot is ismertettünk, például a gyógyszeres kezelés felkutatásában, vagy éppen a súlyos, halálos kimenetelú megbetegedés szempontjából leginkább veszélyeztetettek pontosabb beazonosításának területén, ahol a külön- 
böző adatállományok összekapcsolásának, aggregálásának lenne nagy jelentősége (Gaál-Szócska 2020). Egyre több példa van ugyanakkor arra is, hogy az egyéb környezeti kihívások kezelésében ugyanúgy az egyik leghatékonyabb eszköz az adatok innovatív felhasználása, elemzése. A krónikus nem fertőző betegségekkel való megbirkózásban például fontos a betegutak nyomon követése, de elsődleges jelentőségü a megelőzés is, ahol a személyre szabott üzenetek sokkal hatékonyabb eszközt adhatnak a kezünkbe, ha van bátorságunk felvenni a harcot az élelmiszeripar, vagy éppen a dohányipar nehézsúlyú szereplőivel. Egy biztos: az egészségkárosító életmód fenntartásában érdekelt nagyvállalatok már nagyüzemben használják az ICT-fejlődés adta lehetőségeket termékeik fogyasztásának népszerúsítésére. Ha nem akarunk véglegesen lemaradni ebben a versenyben, akkor az egészség fenntartásában érdekelt szereplőknek is lépniük kell. Ha eddig nem is volt világos a kormányok számára, a COVID-19 világjárvány fájó valósága megmutatta, hogy az egészségügy nem magánügy, hanem az egyik legfontosabb közügy, amely kiemelt nemzetbiztonsági kockázatot hordoz, és ennek megfelelő kezelést igényel.

\section{Köszönetnyilvánítás}

A szerzók köszönetüket fejezik ki Palla Gergelynek a HPV kutatás adatelemzésében nyújtott segítségéért.

\section{Irodalomjegyzék}

Balzotti, C., Bragagnini, A., Briani, M., \& Cristiani, E. (2018) Understanding Human Mobility Flows from Aggregated Mobile Phone Data. IFAC-PapersOnLine, Vol. 51. No. 9. pp. 25-30. DOI: https://doi.org/10.1016/j.ifacol.2018.07.005

Belügyminisztérium Nyilvántartások Vezetéséért Felelős Helyettes Államtitkárság. (2021) Magyarország állandó lakossága. https:// nyilvantarto.hu/hu/statisztikak [Letöltve: 2021. 06. 08.]

Blondel, V. D., Decuyper, A., \& Krings, G. (2015) A survey of results on mobile phone datasets analysis. EPJ Data Science, Vol. 4. No. 1 pp. 10. DOI: 10.1140/epjds/s13688-015-0046-0

Centers for Disease Control and Prevention (2021) When to Quarantine. https://www.cdc.gov/coronavirus/2019-ncov/if-you-aresick/quarantine.html [Letöltve: 2021. 04. 27.]

Conn, D., Lawrence, F., Lewis, P., Carrell, S., Pegg, D., Davies, H., \& Evans, R. (2020) Revealed: the inside story of the UK's Covid-19 crisis. https://www.theguardian.com/world/2020/apr/29/revealed-the-inside-story-of-uk-covid-19-coronavirus-crisis [Letöltve: 2021. 04. 27.]

Denworth, L. (2020) How the COVID-19 Pandemic Could End. https://www.scientificamerican.com/article/how-the-covid19-pandemic-could-end1/ [Letöltve: 2021. 04. 27.]

Doktor Gődény. (2021). Facebook-oldal. https://www.facebook. com/pg/DoktorGodeny/posts / [Letöltve: 2021. 04. 27.]

Dósa, Á., Hanti, P., \& Kovácsy, Z. (2017) Kommentár az egészségügyi törvényhez. Budapest, Wolters Kluwer

Eagle, N. (2011) Mobile Phones as Social Sensors. In: Hesse-Bieber, S. N. (ed.) The Handbook of Emergent Technologies in Social Research. New York, Oxford University Press. pp. 492-521.

Gaal, P. (2004) Health Care Systems in Transition. Hungary, Copenhagen, WHO Regional Office for Europe on behalf of the European Observatory on Health
Gaal, P. (2005) Benefits and entitlements in the Hungarian health care system. Eur J Health Econ, Vol. Suppl. pp. 37-45. DOI: 10.1007/ s10198-005-0317-y

Gaál, P. (2019) Egészség, egészségügy és egészségügyi rendszerek a 21. században. In: Győrffy, Z., \& Szántó, Z. (eds) Orvosi szociológia - eTankönyv. Budapest, Semmelweis Kiadó. pp. 129-153.

Gaal, P., Stefka, N., \& Nagy, J. (2006) Cost accounting methodologies in price setting of acute inpatient services in Hungary. Health Care Manag Sci, Vol. 9. No. 3. pp. 243-250. DOI: 10.1007/ s10729-006-9091-3

Gaal, P., Szigeti, S., Panteli, D., Gaskins, M., \& van Ginneken, E. (2011) Major challenges ahead for Hungarian healthcare. BMJ, Vol. 343. pp. d7657. DOI: 10.1136/bmj.d7657

Gaál, P., \& Szócska, M. (2020) Digitális megoldások a járvány kezelésében - adattudományi innováció és a Covid-19 kihívásai. In: Nógrádi Tóth, E. (szerk.) Medicina évkönyv 2020: A magyar egészségügy számokban. Budapest, Contact Press\&Consulting Bt. pp. 12-15.

Gaal, P., Szocska, M., Joo, T., \& Palicz, T. (2021) Population Movement Monitoring Based on Mobile Phone Usage Data to Support Pandemic Decision Making. ERCIM News. No. 124. pp. 16-17.

Girasek, E., Szocska, M., Kovacs, E., \& Gaal, P. (2017) The role of controllable lifestyle in the choice of specialisation among Hungarian medical doctors. BMC Med Educ, Vol. 17. No. 1. pp. 204. DOI: $10.1186 /$ s12909-017-1031-z

Google Inc. (2020) COVID-19 Community Mobility Reports. https://www.google.com/covid19/mobility [Letöltve: 2020. 05. 20.]

Grantz, K. H., Meredith, H. R., Cummings, D. A. T., Metcalf, C. J. E., Grenfell, B. T., Giles, J. R., Mehta, S., Solomon, S., Labrique, A., Kishore, N., Buckee, C. O., \& Wesolowski, A. (2020) The use of mobile phone data to inform analysis of COVID-19 pandemic epidemiology. Nat Commun, Vol. 11. No. 1. pp. 4961. DOI: 10.1038/s41467-020-18190-5

Helfgott, D. C. (2020) Respiratory Transmission of SARS-CoV-2: What Do We Really Know? https://www.infectiousdiseaseadvisor. com/home/topics/covid19/respiratory-transmission-of-covid19coronavirus/ [Letöltve: 2021. 04. 27.]

Ipsos (2021) 50\% felett az oltási hajlandóság Magyarországon. https://www.ipsos.com/hu-hu/50-felett-az-oltasi-hajlandosagmagyarorszagon [Letöltve: 2021. 04. 27.]

Jacobs, R., Smith, P. C., \& Street, A. (2006) Measuring Efficiency in Health Care: Analytic Techniques and Health Policy. Cambridge, Cambridge University Press

Kormány (2020) 95/2020. (IV. 9.) Korm. rendelet a kijárási korlátozás meghosszabbításáról. Magyar Közlöny, Vol. 2020. No. 69. pp. 1878-1879.

Maragakis, L. L. (2020) Coronavirus, Social and Physical Distancing and Self-Quarantine. https://www.hopkinsmedicine.org/health/ conditions-and-diseases / coronavirus/coronavirus-social-distancing-and-self-quarantine [Letöltve: 2021. 04. 27.]

Munné, R. (2016) Big Data in the Public Sector. In: Cavanillas, J. M., Curry, E., \& Wahlster, W. (eds) New Horizons for a Data-Driven Economy: A Roadmap for Usage and Exploitation of Big Data in Europe. Cham, Springer International Publishing. pp. 195-208. DOI: 10.1007/978-3-319-21569-3_11

Oliver, N., Lepri, B., Sterly, H., Lambiotte, R., Delataille, S., De Nadai, M., Letouzé, E., Salah, A., Benjamins, R., Cattuto, C., Colizza, V., de Cordes, N., Fraiberger, S., Koebe, T., Lehmann, S., Murillo, J., Pentland, A., Pham, P., Pivetta, F., Saramäki, J., Scarpino, S., Tizzoni, M., Verhulst, S., \& Vinck, P. (2020) Mobile phone data for informing public health actions across the COVID-19 pandemic life cycle. Science Advances. pp. 1-10. DOI: $10.1126 /$ sciadv.abc0764

Portfolio (2021) Megbüntették Gődény Györgyöt, Magyarország egyik legismertebb járványtagadóját. https://www.portfolio.hu/ gazdasag/20210308/megbuntettek-godeny-gyorgyot-magyaror- 
szag-egyik-legismertebb-jarvanytagadojat-473184 [Letöltve: 2021. 04. 27.]

Regulatory Management and Reform Group of the Public Management Committee (2000) Reducing the Risk of Policy Failure: Challenges for Regulatory Compliance. https://www.oecd.org/gov/ regulatory-policy/46466287.pdf, Organisation for Economic Co-operation and Development: 1-91.

Scholz, J. T. (1984) Voluntary compliance and regulatory enforcement. Law \& Policy, Vol. 6. No. 4. pp. 385-404. DOI: 10.1111/ j.1467-9930.1984.tb00334.x

Sweeney, L. (2002) K-anonymity: a model for protecting privacy. International Journal on Uncertainty, Fuzziness and Knowledgebased Systems, Vol. 10. No. 5. pp. 557-570.

Szigeti, S., Evetovits, T., Kutzin, J., \& Gaal, P. (2019) Tax-funded social health insurance: an analysis of revenue sources, Hungary. Bull World Health Organ, Vol. 97. No. 5. pp. 335-348. DOI 10.2471/BLT.18.218982

Szocska, M., Pollner, P., Schiszler, I., Joo, T., Palicz, T., McKee, M., Asztalos, A., Bencze, L., Kapronczay, M., Petrecz, P., Toth, B., Szabo, A., Weninger, A., Ader, K., Bacskai, P., Karaszi, P., Terplan, G., Tuboly, G., Sohonyai, A., Szoke, J., Toth, A., \& Gaal, P. (2021) Countrywide population movement monitoring using mobile devices generated (big) data during the COVID-19 crisis. Sci Rep, Vol 11. No. 1. pp. 5943. DOI: 10.1038/s41598-021-81873-6

Thomas, S., Sagan, A., Larkin, J., Cylus, J., Figueras, J., \& Karanikolos, M. (2020) Strengthening health systems resilience: Key concepts and strategies. https://apps.who.int/iris/bitstream/hand-
le/10665/332441/Policy-brief\%2036-1997-8073-eng.pdf [Letöltve: 2021. 04. 26.]

Weintraub, K. (2020) Sweden Sticks With Controversial COVID-19 Approach. https://www.webmd.com/lung/news/20200501/ sweden-sticks-with-controversial-covid19-approach [Letöltve: 2021. 04. 27.]

World Health Organization (2017) Diphtheria tetanus toxoid and pertussis (DTP3) immunization coverage estimates by country. https://apps.who.int/gho/data/node.main.A827!lang=en $\quad[$ Letöltve: 2021.04 .27$.

World Health Organization (2020) Novel Coronavirus - China. www. who.int/csr/don/12-january-2020-novel-coronavirus-china/en/ [Letöltve: 2021. 04. 27.]

World Health Organization (2021a) Coronavirus disease (COVID-19) pandemic. https://www.who.int/emergencies/diseases/novel-coronavirus-2019 [Letöltve: 2021. 04. 27.]

World Health Organization (2021b) Middle East respiratory syndrome coronavirus (MERS-CoV). https://www.who.int/health-to$\mathrm{pics} /$ middle-east-respiratory-syndrome-coronavirus-mers\#tab=tab_l [Letöltve: 2021.04.27.]

World Health Organization $(2021 \mathrm{c})$ Personal protective equipment for COVID-19. https://www.who.int/teams/health-productand-policy-standards/access-to-assistive-technology-medical-devices/medical-devices/ppe/ppe-covid [Letöltve: 2021. 04. 27.]

World Health Organization (2021d) Severe Acute Respiratory Syndrome (SARS). https://www.who.int/health-topics/severe-acuterespiratory-syndrome\#tab=tab_1 [Letöltve: 2021. 04. 27.]

A cikk a Creative Commons Attribution 4.0 International License (https://creativecommons.org/licenses/by/4.0/) feltételei szerint publikált Open Access közlemény, melynek szellemében a cikk bármilyen médiumban szabadon felhasználható, megosztható és újraközölhető, feltéve, hogy az eredeti szerző és a közlés helye, illetve a CC License linkje és az esetlegesen végrehajtott módositások feltüntetésre kerülnek. (SID_1) 